\title{
An Update on the Health Benefits of Green Tea
}

\author{
Wanda C. Reygaert \\ Oakland University William Beaumont School of Medicine, Rochester, MI 48309, USA; \\ reygaert@oakland.edu; Tel.: +1-248-370-2709 \\ Academic Editor: Quan V. Vuong \\ Received: 21 June 2016; Accepted: 19 December 2016; Published: 18 January 2017
}

\begin{abstract}
Green tea, which is produced from the leaves of the Camellia sinensis plant, is one of the most popular beverages worldwide. Over the past 30 years or more, scientists have studied this plant in respect to potential health benefits. Research has shown that the main components of green tea that are associated with health benefits are the catechins. The four main catechins found in green tea are: (-)-epicatechin (EC), (-)-epicatechin-3-gallate (ECG), (-)-epigallocatechin (EGC), and (-)-epigallocatechin-3-gallate (EGCG). Of these four, EGCG is present in the largest quantity, and so has been used in much of the research. Among the health benefits of green tea are: anticarcinogenic, anti-inflammatory, antimicrobial, and antioxidant properties, and benefits in cardiovascular disease and oral health. Research has been carried out using various animal models and cells lines, and is now more and more being carried out in humans. This type of research will help us to better understand the direct benefits of green tea. This review will focus primarily on research conducted using human subjects to investigate the health benefits of green tea.
\end{abstract}

Keywords: green tea; anticarcinogenic; anti-inflammatory; antimicrobial; antioxidant; cardiovascular disease; oral health

\section{Introduction}

Tea is a popular drink worldwide. Cultivation of tea plants is economically important in many countries, and the tea plant, Camellia sinensis (Figure 1), is known to be grown in as many as 30 countries. Camellia sinensis grows best in certain tropical and subtropical regions [1]. There are four main types of tea produced from this same plant, depending on how the tea leaves are processed. These teas are white, green, Oolong, and black tea. White tea is produced from very young leaves and buds that have not yet turned green, and the only processing is drying. Green tea is produced from mature leaves with minimal processing (only drying). Oolong tea is produced from partially fermented mature leaves, and black tea is produced from fully fermented mature leaves [1,2]. Green tea, which makes up around $20 \%$ of tea production worldwide, is consumed most often in China, Korea, and Japan. Oolong tea is consumed most in China and Taiwan. Black tea (around 78\% of tea production) is mostly consumed in the United States and the United Kingdom. Black tea contains up to three times the amount of caffeine as green tea [3-5].

The components of green tea that are the most relevant medically are the polyphenols, with the flavonoids being the most important. The most pertinent flavonoids are the catechins, which make up $80 \%-90 \%$ of the flavonoids, and approximately $40 \%$ of the water-soluble solids in green tea [6-8]. The amount of catechins in the tea can be affected by which leaves are harvested, how the leaves are processed, and how the tea is prepared. In addition, where the leaves are grown (geographically) and the growing conditions affect catechin amounts [3,9-12]. Polyphenols are quickly oxidized after harvesting due to the enzyme polyphenol oxidase. To prevent loss of the polyphenols, green tea leaves are heated rapidly (most commonly by steaming or pan frying) to inactivate polyphenol oxidase. Black tea leaves are dried, then rolled and crushed, which promotes oxidation. Therefore, 
black tea has far fewer active catechins than green tea $[1,2,5,8]$. Green tea contains four main catechins: (-)-epicatechin (EC), (-)-epigallocatechin (EGC), (-)-epicatechin-3-gallate (ECG), and (-)-epigallocatechin-3-gallate (EGCG). The most abundant of these in green tea is EGCG, which represents around $59 \%$ of total catechins. The next most abundant is EGC (around 19\%), then ECG (around 14\%), and EC (around 6\%) [2,3,8]. Figure 2 shows a representation of green tea catechin composition.

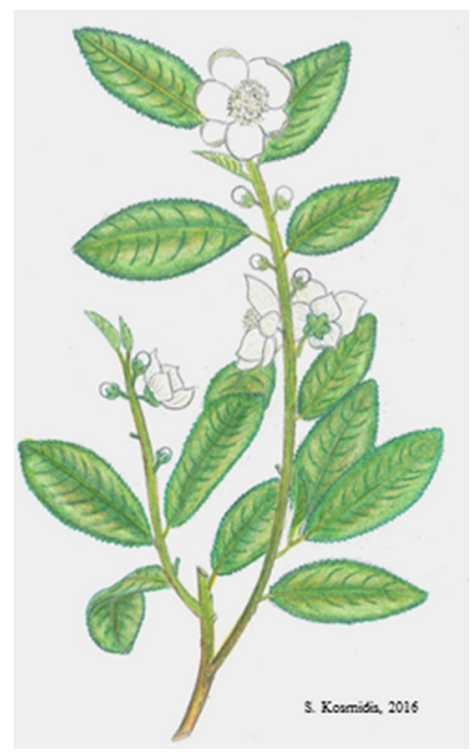

Figure 1. Drawing of the Camellia sinensis plant.

Green Tea Catechins

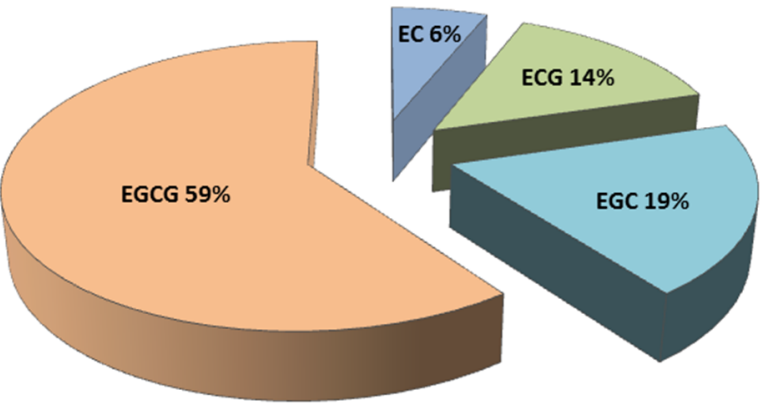

Figure 2. Relative composition of green tea catechins.

The health benefits of green tea depend on its bioavailability after consumption. In the body, the components in green tea may undergo metabolic processing such as glucuronidation, methylation, and sulfation, which produces active metabolites [13]. The catechins and their metabolites may be detected in blood plasma, urine, and various tissues. Studies on bioavailability are often conducted collecting specimens at timed intervals (after ingestion). Various studies have been conducted using normally prepared green tea beverages [14-16], ingested green tea extract (total catechins) $[14,17,18]$, or ingestion of specific catechins [19-21]. These studies have shown that ECG and EGCG, and metabolites of EC and EGC can be detected and measured in blood plasma. In urine, only metabolites of EC and EGC can be detected. Peak concentrations of components in blood plasma generally occur about $2 \mathrm{~h}$ after ingestion. Peak concentrations of components in urine generally occur between 4 and $6 \mathrm{~h}$ after ingestion. Certain studies have been conducted using various concentrations of catechins, and generally show that the bioavailability of these substances is in proportion to the amount 
ingested $[18,19,22-24]$. It has been suggested that levels of EC and ECG detected are too low to be of any therapeutic value, so most research considers only EGC and EGCG [25]. Table 1 shows a summary of the results of some of these studies.

Table 1. Green tea catechin bioavailability studies summary.

\begin{tabular}{ccccc}
\hline Source & Initial Dose Ingested & $\begin{array}{c}\text { Plasma Concentration } \\
\text { (Peak Time) }\end{array}$ & $\begin{array}{c}\text { EGC in Urine/24 h } \\
\text { (Peak Time) }\end{array}$ & References \\
\hline Green tea beverage & EGCG 230-235 $\mu \mathrm{mol}$ & EGCG $55 \mathrm{nmol} / \mathrm{L}(1.9 \mathrm{~h})$ & $33 \mu \mathrm{mol}$ & {$[15]$} \\
& EGC $257-260 \mu \mathrm{mol}$ & EGC $126-205 \mathrm{nmol} / \mathrm{L}(2.2 \mathrm{~h})$ & {$[16]$} \\
\hline \multirow{2}{*}{ Green tea extracts } & EGCG $88-110 \mathrm{mg}$ & EGCG $119-135 \mathrm{ng} / \mathrm{mL}$ & $3.0 \mathrm{mg}(3-6 \mathrm{~h})$ & {$[17]$} \\
& EGC $82-102 \mathrm{mg}$ & EGC $140-148 \mathrm{ng} / \mathrm{mL}$ & {$[18]$} \\
\hline
\end{tabular}

Over the past 15-20 years, a number of other research studies have been conducted to determine what health benefits can be attributed to consumption of green tea and its extracts. This research has shown that green tea has a variety of potential health benefits. These benefits include anticarcinogenic, anti-inflammatory, antimicrobial, and antioxidant properties, and benefits in cardiovascular disease and oral health. While much of this research has been performed in vitro, and a significant amount of the research done in vivo, using animal models, this paper will focus mainly on studies conducted with human subjects (plus pertinent information from the other types of studies).

\section{Anticarcinogenic Properties of Green Tea}

Cancer is currently a major source of morbidity and mortality worldwide. Billions of dollars in research monies have been poured into cancer research over the past 50 plus years, and yet we do not seem to be any closer to actually curing it. In addition, quite often the chemotherapies do as much, if not more damage to the patient as the disease. Because cancer appears in so many different forms in multiple parts of the body, it has been difficult to determine the mechanisms that lead to the disease. Even with what we now know about cancer risk factors, there are still many people who seemingly have none of the risk factors, and yet succumb to a rapidly aggressive form. Encouraging people to think about how a healthy lifestyle can prevent disease is certainly a step in the right direction, and it would be most helpful to identify substances that could be useful in prevention and treatment.

The main component of green tea that has been studied in cancer research is EGCG. There are several cancer related mechanisms attributed to EGCG. These include: inhibition of angiogenesis, DNA hypermethylation, NF- $\mathrm{kB}$, telomerase activity, and tumor cell proliferation and metastasis; induction of tumor suppressor genes; and promotion of tumor cell apoptosis [26-30]. Inhibition of angiogenesis is suggested to occur through a decrease in RNA and peptide levels of vascular endothelial growth factor (VEGF), and by disrupting the dimerization of VEGF with the vascular endothelial growth factor receptor 2 (VEFR2) [31]. Another suggested way in which green tea catechins may generally inhibit carcinogenesis is through increasing levels of glutathione $S$-transferase pi (GST-pi), which catalyzes detoxification reactions that inhibit carcinogen-induced DNA damage [32].

Analysis of studies performed using human oral consumption of green tea to assess cancer risk showed that case-control studies gave the most consistent results and were positive for reduced cancer risk in breast, cardiac, colorectal, esophageal, gastric, lung, ovarian, pancreatic, and prostate cancers [33,34]. A recent large study showed a relationship between breast cancer risk and tea consumption, with the risk being highest in the groups that did not consume tea and lowest in the groups that consumed the most cups per day. Number of cups were assessed in five categories (0.1-1.0 cups, 1.1-2.0 cups, 2.1-3.0 cups, 3.1-5.0 cups, $>5.0$ cups) [35]. Analysis of the types of green tea beverage or extracts used in studies suggests that green tea beverage or a supplement containing mixed catechins may be more effective than using single catechin (e.g., EGCG) supplements [36].

The potential molecular mechanisms and targets that might explain how green tea catechins possess anticarcinogenic properties have been widely studied (using various cell cultures, etc.), 
especially in breast cancers. These include interaction with specific proteins, anti-angiogenesis mechanisms, targets for inhibition of enzyme activities and cell signaling pathways, and induction of cell cycle arrest and apoptosis [37]. Table 2 gives a summary of some of these potential targets and mechanisms.

Table 2. Potential targets and mechanisms of green tea catechins in breast cancer.

\begin{tabular}{|c|c|c|c|c|}
\hline Source & Molecule(s) Affected & Pathway & Result & References \\
\hline \multicolumn{5}{|c|}{ Inhibition of Cancer Cell Growth, Proliferation, Invasion } \\
\hline EGCG & $\begin{array}{c}\text { 67-kDa laminin receptor } \\
(67 \mathrm{LR})\end{array}$ & $\begin{array}{l}\text { Silences } 67 \mathrm{LR} \text { by binding } \\
\text { to it which activates } \\
\text { myosin phosphatase }\end{array}$ & Inhibition of cell growth & [38] \\
\hline EGCG & $\begin{array}{l}\text { Cyclin-dependent kinase } 2 \\
\text { (Cdk2) and } 4 \text { (Cdk4) }\end{array}$ & $\begin{array}{l}\text { Inhibits activity of Cdk2 } \\
\text { and Cdk4 }\end{array}$ & Cell cycle arrest at $G_{1}$ & [39] \\
\hline EGCG & $\begin{array}{c}\text { Dual-specificity } \\
\text { tyrosine-phosphorylated } \\
\text { and regulated kinase 1A } \\
\text { (DYRK1A) }\end{array}$ & Inhibits DYRK1A & $\begin{array}{l}\text { Decreased cell } \\
\text { proliferation }\end{array}$ & [40] \\
\hline EGCG & $\begin{array}{l}\text { Epidermal growth factor } \\
\text { receptor (EGFR) }\end{array}$ & $\begin{array}{l}\text { Down regulates levels of } \\
\text { EGFR protein }\end{array}$ & $\begin{array}{l}\text { Inhibition of cell growth } \\
\text { and invasive activity }\end{array}$ & [41] \\
\hline EGCG & $\begin{array}{l}\text { Estrogen receptor alpha } \\
(\text { ER- } \alpha)\end{array}$ & $\begin{array}{l}\text { Down regulates level of } \\
\text { ER- } \alpha \text { protein }\end{array}$ & $\begin{array}{l}\text { Inhibition of cell } \\
\text { proliferation }\end{array}$ & [42] \\
\hline EGCG & $\begin{array}{l}\text { HMG-Box transcription } \\
\text { factor (HBP1) }\end{array}$ & $\begin{array}{c}\text { Increases levels of HBP1 } \\
\text { which represses } \\
\text { Wnt signaling }\end{array}$ & $\begin{array}{l}\text { Inhibition of cell } \\
\text { invasive activity }\end{array}$ & [43] \\
\hline EGCG & $\begin{array}{l}\text { Human epidermal growth } \\
\text { factor receptor } 2 \text { (HER-2) }\end{array}$ & $\begin{array}{l}\text { Inhibits phosphorylation } \\
\text { of HER-2 }\end{array}$ & Inhibition of cell growth & {$[44,45]$} \\
\hline EGCG & $\begin{array}{l}\text { Hepatocyte growth factor } \\
\text { (HGF) }\end{array}$ & $\begin{array}{l}\text { Inhibits HGF inducing } \\
\text { phosphorylation of its } \\
\text { receptor (Met) }\end{array}$ & $\begin{array}{l}\text { Inhibition of cell motility } \\
\text { and invasive activity }\end{array}$ & [46] \\
\hline EGCG & $\begin{array}{l}\text { Insulin-like growth factor-1 } \\
\text { receptor (IGF-1R) }\end{array}$ & $\begin{array}{l}\text { Binds to IGF-1R and } \\
\text { inhibits its kinase activity }\end{array}$ & $\begin{array}{l}\text { Inhibition of cell } \\
\text { proliferation and } \\
\text { transformation }\end{array}$ & [47] \\
\hline EGCG & $\begin{array}{l}\text { Phosphoinositide-3-kinase } \\
\text { (PI3K) }\end{array}$ & $\begin{array}{c}\text { Binds to PI3K kinase } \\
\text { domain competing } \\
\text { with ATP }\end{array}$ & $\begin{array}{l}\text { Inhibition of cell } \\
\text { proliferation }\end{array}$ & [48] \\
\hline $\begin{array}{l}\text { Green tea extract } \\
\text { (GTE) }\end{array}$ & $\begin{array}{l}\text { Vascular endothelial growth } \\
\text { factor (VEGF) }\end{array}$ & $\begin{array}{l}\text { Inhibits transcription of } \\
\text { VEGF }\end{array}$ & $\begin{array}{l}\text { Decreased tumor cell } \\
\text { blood vessel density, } \\
\text { inhibition } \\
\text { of proliferation }\end{array}$ & [49-51] \\
\hline EGCG & $\begin{array}{l}\text { Intermediate filament } \\
\text { vimentin }\end{array}$ & $\begin{array}{l}\text { Binds to vimentin } \\
\text { inhibiting its } \\
\text { phosphorylation }\end{array}$ & $\begin{array}{l}\text { Inhibition of cell } \\
\text { proliferation }\end{array}$ & [52] \\
\hline \multicolumn{5}{|c|}{ Induction of Apoptosis } \\
\hline EGCG & $\begin{array}{l}\text { B-cell lymphoma-extra large } \\
\text { protein }\left(B c l-x_{L}\right)\end{array}$ & $\begin{array}{l}\text { Binds in the P1 pocket } \\
\text { of Bcl- } \mathrm{x}_{\mathrm{L}}\end{array}$ & $\begin{array}{l}\text { Suppression of } \\
\text { anti-apoptosis }\end{array}$ & [53] \\
\hline $\begin{array}{l}\text { EGCG, green tea } \\
\text { catechins }\end{array}$ & $\begin{array}{l}\text { Caspase-3, }-8,-9 \text {; tumor } \\
\text { protein } 53(\mathrm{p} 53)\end{array}$ & $\begin{array}{l}\text { Increased expression of } \\
\text { caspase- } 3,-8,-9, \text { and p53 }\end{array}$ & Induction of apoptosis & [54-56] \\
\hline EGCG & $\begin{array}{l}\text { Glucose-regulated protein } 78 \\
\text { (GRP78) }\end{array}$ & $\begin{array}{l}\text { Binds GPR78 at } \\
\text { ATP-binding site }\end{array}$ & $\begin{array}{l}\text { Suppression of } \\
\text { anti-apoptosis }\end{array}$ & [57] \\
\hline
\end{tabular}

The mushrooming area of nanotechnology has lead to the development of potential chemotherapy involving nanoparticles (NPs). Various particles (e.g., gold) can be used to deliver compounds to specific areas of the body. Research using EGCG and nanoparticles has already begun using a number of delivery approaches. These include: coating an NP, such as gold, with EGCG; use of encapsulated (in liposomes or polymeric NPs) EGCG in NPs along with anti-cancer drugs, outer ligands that will bind to specific targets, or outer polymers that will enhance the intestinal absorption of EGCG [30]. 


\section{Cardiovascular Disease Health Benefits}

Cardiovascular disease (CVD) is a complex disorder involving multiple factors. Among those factors are inflammation, oxidative stress, platelet aggregation, and lipid metabolism. Some of these factors are also involved in other disease processes, but will be discussed in this paper under CVD. There have been a number of studies over the years assessing green tea consumption in respect to CVD risk [58]. Two studies from Japan that included nearly 50,000 people found a decreased mortality rate due to CVD based on consumption of various numbers of cups per day. One study showed a $28 \%$ decrease in CVD death between those who consumed $\leq 3$ cups and those who consumed $\geq 10$ cups. The other study showed a 14\% decrease in CVD mortality between those who consumed $<1$ cup and those who consumed $\geq 5$ cups $[59,60]$. Other studies in Japan using a green tea extract found that, after 12 weeks, the subjects had reductions in body fat (10\%), blood pressure (6.5\%), and low-density lipoprotein (LDL) levels (2.6\%), suggesting reduced risk of CVD. After two months, diabetic patients also had reduced fasting blood glucose levels (from 135 to $128.8 \mathrm{mg} / \mathrm{dL}$ ), and hemoglobin A1c (HBA1c) levels (from $6.2 \%$ to $6.0 \%$ ) [61,62]. A large meta-analysis of 17 studies from over 30 years, including data from Europe, the UK, and the U.S., found that increasing consumption of green tea by three cups per day decreased the risk of myocardial infarction (MI) death by $11 \%$ [63]. Another study showed a decreased risk of mortality in patients who had an acute MI and a history of regular green tea consumption for at least a year prior to the MI. Participants who did not drink green tea had a $14 \%$ rate of death due to the MI; participants who drank up to 14 cups per week had an $11 \%$ rate of MI death; and participants who drank more than 14 cups per week had a $10 \%$ rate of MI death [64]. An interesting study in patients with CVD showed that consumption of EGCG resulted in a rapid improvement of vascular endothelial function. Participants who ingested an initial dose of $300 \mathrm{mg}$ of EGCG had an improved brachial artery flow-mediated dilation from $7.1 \%$ to $8.6 \%$ after $2 \mathrm{~h}$ [65]. Another recent study found that increased intake of dietary flavonoids was associated with a decreased risk of CVD. The participants were divided into three groups based on average daily consumption of flavonoids. The first tertile consumed $89 \mathrm{mg} /$ day, the second tertile consumed $251 \mathrm{mg} /$ day, and the third tertile consumed $532 \mathrm{mg} /$ day. The number of deaths due to CVD in the first tertile was $8.6 \%$; in the second tertile, $6.4 \%$; and in the third tertile, $5.0 \%$ [66].

\subsection{Inflammation}

Besides CVD, inflammation is also involved in arthritis, aging, cancer, etc. Many of the anti-inflammatory effects when using green tea have been studied in rheumatoid arthritis (RA) and osteoarthritis (OA), and are pertinent to CVD as well. Some general anti-inflammatory mechanisms of green tea components are: increased production of the anti-inflammatory cytokine, IL-10; regulation of IL-6 synthesis and signaling; decreased production of destructive matrix metalloproteinases via TNF- $\alpha$ induced phosphorylation of mitogen-activated protein kinases (MAPKs); and decreased expression of the chemokine receptor CCR2 and decreased levels of the proinflammatory cytokines IL- $1 \beta$ and TNF- $\alpha[2,67-70]$.

The specific studies on inflammation can be roughly categorized into: inhibition of neutrophil-endothelium interaction, modulation of neutrophil functions and death, and regulation of inflammation factors. Neutrophil migration and function is an integral part of the inflammatory response, so controlling neutrophils is vital in decreasing inflammation. Studies have shown that green tea catechins cause a reduction in the number of leukocyte-endothelial cell adhesion molecules (CAMs), such as ICAM-1, VCAM-1, and E-selection, expressed on the endothelial cell surface. This restricts the ability of the neutrophils to migrate to sites of infection [71,72]. Other studies have shown that factors known to regulate neutrophil function, such as IL-1 $\beta$, IL-2, TNF- $\alpha$, and granulocyte-macrophage colony-stimulating factor (GM-CSF), are suppressed by consumption of green tea or EGCG, resulting in inhibition of inflammation [73-75]. Studies on the inhibition of pro-inflammatory factors have shown that green tea catechins downregulate many inflammatory 
chemokines, cytokines, and inflammatory markers such as: IL- $1 \alpha$, IL-1 $\beta$, IL-6, IL-8, Interferon gamma (INF- $\gamma$ ), and C-reactive protein (CRP) [74,76-78].

\subsection{Oxidative Stress}

Oxidative stress in the body is closely tied to inflammation and CVD, and is the result of the damaging effects of reactive oxygen species (ROS). These ROS are capable of causing chronic inflammation through induction of inflammatory cytokines and chemokines, and pro-inflammatory transcription factors. In general, green tea catechins have been found to have antioxidant activity through: inhibiting redox sensitive transcription factors and pro-oxidant enzymes, scavenging ROS, and inducing anti-oxidant enzymes [8].

Studies to determine the antioxidant capabilities of green tea may measure a variety of substances. Tests may measure the presence of known ROS or their metabolites, such as hydroxyl radical, peroxides, superoxide, and singlet oxygen. Other measurements may be for known antioxidant substances such as superoxide dismutase (SOD) and glutathione peroxidase, or substances that indicate inflammation such as high-sensitivity C-reactive protein (hs-CRP) and TNF- $\alpha$. Another type of testing assesses total antioxidant capacity (TAC), also known as total antioxidant status (TAS), which measures the amount of oxidants that are neutralized in the body (e.g., moles of oxidant neutralized by $1 \mathrm{~L}$ of plasma), with a lower number translating into a higher risk of disease [67].

The results from recent studies have shown that green tea catechins can affect levels of ROS [79-82], increase levels of antioxidants [83-86], decrease levels of inflammatory substances [87,88], and increase TAC (TAS) $[84,86,87]$. An excellent summary of earlier studies that measured ROS and TAC can be found in a chapter by Serafini et al. 2011 [67].

\subsection{Platelet Aggregation}

Platelet activation and subsequent aggregation play an important role in CVD. When the vascular endothelium is damaged, platelets usually respond rapidly and aggregate to form plugs at the damage site, and may also form clots that could lead to vessel occlusion [8,89]. Many of the studies on platelet aggregation have been carried out using various animal platelets. In addition to showing that green tea catechins were involved in inhibition of platelet aggregation, studies suggested that catechins may affect several cellular targets that are related to platelet activation, including: through the arachadonic acid pathway, inhibition of a cytoplasmic increase in calcium, decreased thrombaxane $\mathrm{A}_{2}$ (TXA ${ }_{2}$ ) production, and inhibition of cyclooxygenase-1 (COX)-1 [90-93]. A study using human platelets concluded that EGCG was able to inhibit platelet activation by adenosine diphosphate (ADP) stimulation, and suppressed the p38 MAPK phosphorylation of heat shock protein 27 (HSP27), which would inhibit the release of pro-thrombotic contents from platelets [94].

\subsection{Lipid Metabolism}

Increased blood lipid levels have long been suspected as an increased risk for CVD, especially LDLs [95]. One mechanism that is linked with atherosclerosis is the presence of oxidated LDL [96]. There have been many studies performed using humans subjects to determine the effect of green tea catechins on lipids. The studies have reported that consumption of green tea catechins lowers total cholesterol and LDL levels and also reduces blood pressure [87,97-104]. In addition, a recent study found that green tea catechins are incorporated into LDL particles, and are then able to reduce the oxidation of LDL. Catechins prevent LDL oxidation via radical-trapping abilities and act as hydrogen donors to $\alpha$-tocopherol radicals [105].

\section{Antimicrobial Properties}

A large amount of research has been performed assessing the antimicrobial scope of green tea catechins. Organisms affected by green tea include a large number of Gram-positive and Gram-negative aerobic bacteria, anaerobic bacteria, viruses, fungi, and at least one parasite (see Table 3). Among 
the antimicrobial mechanisms that have been attributed to green tea are: damage to the bacterial cell membrane, inhibition of bacterial fatty acid synthesis, inhibition of other enzymes (e.g., protein tyrosine kinase, cysteine proteinases, DNA gyrase, ATP synthase), and inhibition of efflux pump activity [25].

Not only do green tea catechins exhibit direct effects on microorganisms, but they also show activities related to the prevention of infection. Studies using mice and ferrets showed that consumption of green tea could inhibit transmission of bacteria and viruses; and studies with humans showed that consumption of green tea resulted in fewer fever illnesses, fewer illnesses with cold or influenza symptoms, and fewer actual infections with Influenza A or B [106].

Table 3. Organisms affected by green tea [106].

\begin{tabular}{cccc}
\hline Bacteria & Viruses & Fungi & Parasites \\
\hline Acinetobacter baumannii & Epstein-Barr virus & Actinomyces spp. & Trypanosoma cruzi \\
Bacillus cereus & Hepatitis B & Aspergillus niger & \\
Escherichia coli (intestinal) & Hepatitis C & Candida albicans & \\
Escherichia coli (uropathogenic) & HIV-1 & \\
Enterococcus faecalis & HSV-1 & \\
Helicobacter pylori & Influenza A H1N1 & \\
Listeria monocytogenes & Influenza A H3N2 & \\
Porphyromonas gingivalis & Influenza A H5N2 & \\
Prevotella intermedia & Influenza B & \\
Proteus mirabilis & & \\
Pseudomonas aeruginosa & & \\
Salmonella typhi & & \\
Salmonella typhimurium & & \\
Staphylococcus aureus & & \\
Staphylococcus epidermidis & & \\
Stenotrophomonas maltophilia & & \\
Streptococcus mutans & & \\
Streptococcus pyogenes & & \\
Vibrio cholerae & & \\
Yersinia enterocolitica & & \\
\hline Abbreviations: HIV-1, & & \\
\hline
\end{tabular}

Abbreviations: HIV-1, Human immunodeficiency virus-1; HSV-1, Herpes simplex virus-1.

\section{Oral Health Benefits}

During the course of the many research studies done using green tea catechin consumption, it was noticed that the research subjects seemed to have improved oral health after consumption. Research was then launched to focus on the effects of green tea on oral health. Two of the general ways in which green tea consumption helps oral health are due to its anti-inflammatory properties, and antimicrobial activity against mouth flora such as Streptococcus mutans $[1,107,108]$. The antimicrobial activity may also be responsible for the improvement observed as to bad breath [109]. The two major types of effects on oral health are a decrease in periodontist and dental caries.

\subsection{Periodontitis}

Green tea consumption has been found to result in decreased tooth loss, and prevent the development and progression of periodontitis. Green tea consumption also has positive effects on periodontal health when assessed as to probing depth, attachment loss, gingival bleeding, and dentin erosion. In addition to the antimicrobial effects on the main bacteria involved in gingivitis, Porphyromonas gingivalis, EGCG has been shown to inhibit the ability of the bacteria to bind to oral epithelial cells via fimbriae, and has also been shown to inactivate bacterial collagenases. EGCG also inhibits production of matrix metalloproteins and IL-8, which are responsible for initiating tissue destruction $[107,108,110,111]$. 


\subsection{Dental Caries}

Prevention of dental caries is attributed to the ability of EGCG to bind and inhibit salivary and bacterial amylases, in particular, $\alpha$-amylase. EGCG also prevents generation of acid from carbohydrates through inhibiting the transcription and function of LDH. One of the main things that encourages tooth decay is that the major oral bacteria (e.g., Streptococcus mutans) form a biofilm on the surface of teeth. EGCG inhibits the adherence of the bacteria to teeth, decreases biofilm formation, and inhibits the ability of the bacteria to produce an acid environment. EGCG also inhibits the hydrogen binding and hydrophobic interactions of bacterial collagenases. Consumption of green tea has also been associated with an increase in oral peroxidase activity $[107,111-113]$.

\section{Conclusions}

Green tea catechins have proved to be very versatile in providing health benefits. This means that there are potential health benefits for everyone in the consumption of green tea. Even moderate amounts of consumption (drinking 1-2 cups of tea per day) may have benefits. It is a very good thing that it is the second most popular beverage worldwide, as the differences in health in a world without green tea might be significant. There is fortunately a wide variety of research being performed using green tea catechins, and we are starting to see many studies performed using human subjects, as it is extremely important that we are able to show the direct benefits to humans. The expansive repertoire of green tea activity in health is important, especially to those people who live where medical assistance is not generally available or affordable.

Conflicts of Interest: The author declares no conflicts of interest.

\section{References}

1. Gupta, D.A.; Bhaskar, D.J.; Gupta, R.K.; Karim, B.; Jain, A.; Dalai, D.R. Green tea: A review on its natural anti-oxidant therapy and cariostatic benefits. Biol. Sci. Pharm. Res. 2014, 2, 8-12.

2. Jigisha, A.; Nishant, R.; Navin, K.; Pankaj, G. Green tea: A magical herb with miraculous outcomes. Int. Res. J. Pharm. 2012, 3, 139-148.

3. Cabrera, C.; Artacho, R.; Gimenez, R. Beneficial effects of green tea-A review. J. Am. Coll. Nutr. 2006, 25, 79-99. [CrossRef] [PubMed]

4. Botten, D.; Fugalio, G.; Fraternali, F.; Molteni, C. Structural properties of green tea catechins. J. Phys. Chem. B 2015, 119, 12860-12867. [CrossRef] [PubMed]

5. Hayat, K.; Iqbal, H.; Malik, U.; Bilal, U.; Mushtaq, S. Tea and its consumption: Benefits and risks. Crit. Rev. Food Sci. Nutr. 2015, 55, 939-954. [CrossRef] [PubMed]

6. Wang, Y.; Ho, C.T. Polyphenolic chemistry of tea and coffee: A century of progress. J. Agric. Food Chem. 2009, 57, 8109-8114. [CrossRef] [PubMed]

7. Roowi, S.; Stalmach, A.; Mullen, W.; Lean, M.E.; Edwards, C.A.; Crozier, A. Green tea flavan-3-ols: Colonic degradation and urinary excretion of catabolites by humans. J. Agric. Food Chem. 2010, 58, 1296-1304. [CrossRef] [PubMed]

8. Babu, P.V.; Liu, D. Green tea catechins and cardiovascular health: An update. Curr. Med. Chem. 2008, 15, 1840-1850. [CrossRef] [PubMed]

9. Fernandez, P.L.; Pablos, F.; Martin, M.J.; Gonzalez, A.G. Study of catechin and xanthine tea profiles as geographical tracers. J. Agric. Food Chem. 2002, 59, 1833-1839. [CrossRef]

10. Lin, Y.S.; Tsai, Y.J.; Tsay, J.S.; Lin, J.K. Factors affecting the levels of tea polyphenols and caffeine in tea leaves. J. Agric. Food Chem. 2003, 51, 1864-1873. [CrossRef] [PubMed]

11. Liu, M.; Tian, H.I.; Wu, J.H.; Cao, R.R.; Wang, R.X.; Qi, X.H.; Xu, Q.; Chen, X.H. Relationship between gene expression and the accumulation of catechin during spring and autumn in tea plants (Camellia sinensis L.). Hortic. Res. 2015, 2, 15011. [CrossRef] [PubMed]

12. Lantano, C.; Rinaldi, M.; Cavazza, A.; Barbanti, D.; Corradini, C. Effects of alternative steeping methods on composition, antioxidant property and colour of green, black and oolong tea infusions. J. Food Sci. Technol. 2015, 52, 8276-8283. [CrossRef] [PubMed] 
13. Lambert, J.D.; Sang, S.; Yang, C.S. Biotransformation of green tea polyphenols and the biological activities of those metabolites. Mol. Pharm. 2007, 4, 819-825. [CrossRef] [PubMed]

14. Henning, S.M.; Niu, Y.; Lee, N.H.; Thames, G.D.; Minutti, R.R.; Wang, H.; Go, V.L.; Heber, D. Bioavailability and antioxidant activity of tea flavanoids after consumption of green tea, black tea, or a green tea extract supplement. Am. J. Clin. Nutr. 2004, 80, 1558-1564. [PubMed]

15. Stalmach, A.; Troufflard, S.; Serafini, M.; Crozier, A. Absorption, metabolism and excretion of Choladi green tea flavan-3-ols by humans. Mol. Nutr. Food Res. 2009, 53, S44-S53. [CrossRef] [PubMed]

16. Clifford, M.N.; van der Hooft, J.J.; Crozier, A. Human studies on the absorption, distribution, metabolism, and excretion of tea polyphenols. Am. J. Clin. Nutr. 2013, 98, 1619S-1630S. [CrossRef] [PubMed]

17. Lee, M.J.; Wang, Z.Y.; Li, H.; Chen, L.; Sun, Y.; Gobbo, S.; Balentine, D.A.; Yang, C.S. Analysis of plasma and urinary tea polyphenols in human subjects. Cancer Epidemiol. Biomark. Prev. 1995, 4, 393-399.

18. Yang, C.S.; Chen, L.; Lee, M.J.; Balentine, D.; Kuo, M.C.; Schantz, S.P. Blood and urine levels of tea catechins after ingestion of different amounts of green tea by human volunteers. Cancer Epidemiol. Biomark. Prev. 1998, 7, 351-354.

19. Chow, H.H.; Cai, Y.; Alberts, D.S.; Hakim, I.; Dorr, R.; Shahi, F.; Crowell, J.A.; Yang, C.S.; Hara, Y. Phase I pharmacokinetic study of tea polyphenols following single-dose administration of epigallocatechin gallate and polyphenon E. Cancer Epidemiol. Biomark. Prev. 2001, 10, 53-58.

20. Van Amelsvoort, J.M.; Van Hof, K.H.; Mathot, J.N.; Mulder, T.P.; Wiersma, A.; Tijburg, L.B. Plasma concentrations of individual tea catechins after a single oral dose in humans. Xenobiotica 2001, 31, 891-901. [CrossRef] [PubMed]

21. Clarke, K.A.; Dew, T.P.; Watson, R.E.; Farrar, M.D.; Bennett, S.; Nicolaou, A.; Rhodes, L.E.; Williamson, G. High performance liquid chromatography tandem mass spectrometry dual extraction method for identification of green tea catechin metabolites excreted in human urine. J. Chromatogr. B Analyt. Techonol. Biomed. Life Sci. 2014, 1, 29-37. [CrossRef] [PubMed]

22. Chow, H.H.; Cai, Y.; Hakim, I.A.; Crowell, J.A.; Shahi, F.; Brooks, C.A.; Dorr, R.T.; Hara, Y.; Alberts, D.S. Pharmacokinetics and safety of green tea polyphenols after multiple-dose administration of epigallocatechin gallate and polyphenon E in healthy individuals. Clin. Cancer Res. 2003, 9, 3312-3319. [PubMed]

23. Nakagawa, K.; Okuda, S.; Miyazawa, T. Dose-dependent incorporation of tea catechins, (-)-epigallocatechin3-gallate and (-)-epigallocatechin, into human plasma. Biosci. Biotechnol. Biochem. 1997, 61, 1981-1985. [CrossRef] [PubMed]

24. Ullmann, U.; Haller, J.; Decourt, J.P.; Girault, N.; Girault, J.; Richard-Caudron, A.S.; Pineau, B.; Weber, P. A single ascending dose study of epigallocatechin gallate in healthy volunteers. J. Int. Med. Res. 2003, 31, 88-101. [CrossRef] [PubMed]

25. Reygaert, W.C. The antimicrobial possibilities of green tea. Front. Microbiol. 2014, 5, 434. [CrossRef] [PubMed]

26. Shirakami, Y.; Shimizu, M.; Moriwaki, H. Cancer chemoprevention with green tea catechins: From bench to bed. Curr. Drug Targets 2012, 13, 1842-1857. [CrossRef] [PubMed]

27. Henning, S.M.; Wang, P.; Carpenter, C.L.; Heber, D. Epigenetic effects of green tea polyphenols in cancer. Epigenomics 2013, 5, 729-741. [CrossRef] [PubMed]

28. Subramani, C.; Natesh, R.K. Molecular mechanisms and biological implications of green tea polyphenol, (-)-epigallocatechin-3-gallate. Int. J. Pharm. Biosci. Technol. 2013, 1, 54-63.

29. Butt, M.S.; Ahmad, R.S.; Sultan, M.T.; Qayyum, M.M.; Naz, A. Green tea and anticancer perspectives: Updates from last decade. Crit. Rev. Food Sci. Nutr. 2015, 55, 792-805. [CrossRef] [PubMed]

30. Granja, A.; Pinheiro, M.; Reis, S. Epigallocatechin gallate nanodelivery systems for cancer therapy. Nutrients 2016, 8, E307. [CrossRef]

31. Yang, C.S.; Wang, H.; Li, G.X.; Yang, Z.; Guan, F.; Jin, H. Cancer prevention by tea: Evidence from laboratory studies. Pharmacol. Res. 2011, 64, 113-122. [CrossRef] [PubMed]

32. Yang, C.S. Antioxidant and anti-carcinogenic activities of tea polyphenols. Arch. Toxicol. 2009, 83, 11-21. [CrossRef] [PubMed]

33. Ju, J.; Lu, G.; Lambert, J.D.; Yang, C.S. Inhibition of carcinogenesis by tea constituents. Semin. Cancer Biol. 2007, 17, 395-402. [CrossRef] [PubMed]

34. Boehm, K.; Borelli, F.; Ernst, E.; Habacher, G.; Hung, S.K.; Milazzo, S.; Hornebar, M. Green tea (Camellia sinensis) for the prevention of cancer. Cochrane Database Syst. Rev. 2009, 3. [CrossRef] 
35. Bhoo-Pathy, N.; Peeters, P.H.; van Gils, C.; Beulens, J.W.; van der Graaf, Y.; Bueno-de-Mesquita, B.; Bulgiba, A.; Uiterwaal, C.S. Coffee and tea intake and risk of breast. Breast Cancer Res. Treat. 2010, 121, 461-467. [CrossRef] [PubMed]

36. Bode, A.M.; Dong, Z. Epigallocatechin 3-gallate and green tea catechins: United they work, divided they fall. Cancer Prev. Res. (Phila.) 2009, 2, 514-517. [CrossRef] [PubMed]

37. Li, M.J.; Yin, Y.C.; Wang, J.; Jiang, Y.F. Green tea compounds in breast cancer prevention and treatment. World J. Clin. Oncol. 2014, 5, 520-528. [CrossRef] [PubMed]

38. Umeda, D.; Yano, S.; Yamada, K.; Tachibana, H. Green tea polyphenol epigallocatechin-3-gallate signaling pathway through 67-kDa laminin receptor. J. Biol. Chem. 2008, 283, 3050-3058. [CrossRef] [PubMed]

39. Liang, Y.C.; Lin-Shiau, S.Y.; Chen, C.F.; Lin, J.K. Inhibition of cyclin-dependent kinases 2 and 4 activities as well as induction of Cdk inhibitors p21 and p27 during growth arrest of human breast carcinoma cells by (-)-epigallocatechin-3-gallate. J. Cell. Biochem. 1999, 75, 1-12. [CrossRef]

40. Bain, J.; McLauchlan, H.; Elliott, M.; Cohen, P. The specificities of protein kinase inhibitors: An update. Biochemistry 2003, 371 Pt 1, 199-204.

41. Farabegoli, F.; Papi, A.; Orlandi, M. (-)-Epigallocatechin-3-gallate down-regulates EGFR, MMP-2, MMP-9 and EMMPRIN and inhibits the invasion of MCF-7 tamoxifen-resistant cells. Biosci. Rep. 2011, 31, 99-108. [CrossRef] [PubMed]

42. De Amicis, F.; Russo, A.; Avena, P.; Santoro, M.; Vivacqua, D.; Bonofiglio, D.; Mauro, L.; Aquila, S.; Tramontano, D.; Fuqua, S.A.; Ando, S. In vitro mechanism for downregulation of ER- $\alpha$ expression by epigallocatechin gallate in ER+/PR+ human breast cancer cells. Mol. Nutr. Food Res. 2013, 57, 840-853. [CrossRef] [PubMed]

43. Kim, J.; Zhang, X.; Rieger-Christ, K.M.; Summerhaves, I.C.; Wazer, D.E.; Paulson, K.E.; Yee, A.S. Suppression of Wnt signaling by the green tea compound (-)-epigallocatechin 3-gallate (EGCG) in invasive breast cancer cells. Requirement of the transcriptional repressor HBP1. J. Biol. Chem. 2006, 281, 10865-10875. [CrossRef] [PubMed]

44. Pianetti, S.; Guo, S.; Kavanagh, K.T.; Sonenshein, G.E. Green tea polyphenol epigallocatechin-3-gallate inhibits Her-2/neu signaling, proliferation, and transformed phenotype of breast cancer cells. Cancer Res. 2002, 62, 652-655. [PubMed]

45. Masuda, M.; Suzui, M.; Lim, J.T.; Weinstein, I.B. Epigallocatechin-3-gallate inhibits activation of HER-2/neu and downstream signaling pathways in human head and neck and breast carcinoma cells. Clin. Cancer Res. 2003, 9, 3486-3491. [PubMed]

46. Bigelow, R.L.; Cardelli, J.A. The green tea catechins, (-)-epigallocatechin-3-gallate (EGCG) and (-)-epicatechin-3-gallate (ECG), inhibit HGF/Met signaling in immortalized and tumorigenic breast epithelial cells. Oncogene 2006, 25, 1922-1930. [CrossRef] [PubMed]

47. Li, M.; He, Z.; Ermakova, S.; Zheng, D.; Tang, F.; Cho, Y.Y.; Zhu, F.; Ma, W.Y.; Sham, Y.; Rogozin, E.A.; et al. Direct inhibition of insulin-like growth factor-I receptor kinase activity by (-)-epigallocatechin-3-gallate regulates cell transformation. Cancer Epidemiol. Biomark. Prev. 2007, 16, 598-605. [CrossRef] [PubMed]

48. Van Aller, G.S.; Carson, J.D.; Tang, W.; Peng, H.; Zhao, L.; Copeland, R.A.; Tummino, P.J.; Luo, L. Epigallocatechin gallate (EGCG), a major component of green tea, is a dual phosphoinositide-3-kinase/mTOR inhibitor. Biochem. Biophys. Res. Commun. 2011, 406, 194-199. [CrossRef] [PubMed]

49. Masuda, M.; Suzui, M.; Lim, J.T.; Deguchi, A.; Soh, J.W.; Weinstein, I.B. Epigallocatechin-3-gallate decreases VEGF production in head and neck and breast carcinoma cells by inhibiting EGFR-related pathways of signal transduction. J. Exp. Ther. Oncol. 2002, 2, 350-359. [CrossRef] [PubMed]

50. Sartippour, M.R.; Shao, Z.M.; Heber, D.; Beatty, P.; Zhang, L.; Liu, C.; Go, V.L.; Brooks, M.N. Green tea inhibits vascular endothelial growth factor (VEGF) induction in human breast cancer cells. J. Nutr. 2002, 132, 2307-2311. [PubMed]

51. Braicu, C.; Gherman, C.D.; Irimie, A.; Berindan-Neagoe, I. Epigallocatechin-3-gallate (EGCG) inhibits cell proliferation and migratory behaviour of triple negative breast cancer cells. J. Nanosci. Nanotechnol. 2013, 13, 632-637. [CrossRef] [PubMed]

52. Ermakova, S.; Choi, B.Y.; Choi, H.S.; Kang, B.S.; Bode, A.M.; Dong, Z. The intermediate filament protein vimentin is a new target for epigallocatechin gallate. J. Biol. Chem. 2005, 280, 16882-16890. [CrossRef] [PubMed] 
53. Leone, M.; Zhai, D.; Sareth, S.; Kitada, S.; Reed, J.C.; Pellecchia, M. Cancer prevention by tea polyphenols is linked to their inhibition of antiapoptotic Bcl-2-family proteins. Cancer Res. 2003, 63, 8118-8121. [PubMed]

54. Islam, S.; Islam, N.; Kermode, T.; Johnstone, B.; Mukhtar, H.; Moskowitz, R.W.; Goldber, V.M.; Malemud, C.J.; Haqqi, T.M. Involvement of caspase-3 in epigallocatechin-3-gallate-mediated apoptosis of human chondrosarcoma cells. Biochem. Biophys. Res. Commun. 2000, 270, 793-797. [CrossRef] [PubMed]

55. Roy, A.M.; Baliga, M.S.; Katiyar, S.K. Epigallocatechin-3-gallate induces apoptosis in estrogen receptor-negative human breast carcinoma cells via modulation in protein expression of p53 and Bax and caspase-3 activation. Mol. Cancer Ther. 2005, 4, 81-90. [PubMed]

56. Alshatwi, A.A. Catechin hydrate suppresses MCF-7 proliferation through TP53/Caspase-mediated apoptosis. J. Exp. Clin. Cancer Res. 2010, 29, 167. [CrossRef] [PubMed]

57. Ermakova, S.P.; Kang, B.S.; Choi, B.Y.; Choi, H.S.; Schuster, T.F.; Ma, W.Y.; Bode, A.M.; Dong, Z. (-)-Epigallocatechin gallate overcomes resistance to etoposide-induced cell death by targeting the molecular chaperone glucose-regulated protein 78. Cancer Res. 2006, 66, 9260-9269. [CrossRef] [PubMed]

58. Jochmann, N.; Baumann, G.; Stangl, V. Green tea and cardiovascular disease: From molecular targets towards human health. Curr. Opin. Clin. Nutr. Metab. Care 2008, 11, 758-765. [CrossRef] [PubMed]

59. Nakachi, K.; Matsuyama, S.; Miyake, S.; Suganuma, M.; Imai, K. Preventive effects of drinking green tea on cancer and cardiovascular disease: Epidemiological evidence for multiple targeting prevention. Biofactors 2000, 13, 49-54. [CrossRef] [PubMed]

60. Kuriyama, S.; Shimazu, T.; Ohmori, K.; Kikuchi, N.; Nakaya, N.; Nishino, Y.; Tsubono, Y.; Tsuji, I. Green tea consumption and mortality due to cardiovascular disease, cancer, and all causes in Japan: The Ohsaki study. JAMA 2006, 296, 1255-1265. [CrossRef] [PubMed]

61. Nagao, T.; Hase, T.; Tokimitsu, I. A green tea extract high in catechins reduces body fat and cardiovascular risks in humans. Obesity (Silver Spring) 2007, 15, 1473-1483. [CrossRef] [PubMed]

62. Fukino, Y.; Shimbo, M.; Aoki, N.; Okubo, T.; Iso, H. Randomized controlled trial for an effect of green tea consumption on insulin resistance and inflammation markers. J. Nutr. Sci. Vitaminol. (Tokyo) 2005, 51, 335-342. [CrossRef] [PubMed]

63. Peters, U.; Poole, C.; Arab, L. Does tea affect cardiovascular disease? A meta-analysis. Am. J. Epidemiol. 2001, 154, 495-503. [CrossRef] [PubMed]

64. Mukamal, K.J.; Maclure, M.; Muller, J.E.; Sherwood, J.B.; Mittleman, M.A. Tea consumption and mortality after acute myocardial infarction. Circulation 2002, 105, 2476-2481. [CrossRef] [PubMed]

65. Widlanski, M.E.; Hamburg, N.M.; Anter, E.; Holbrook, M.; Kahn, D.F.; Elliott, J.G.; Keaney, J.F., Jr.; Vita, J.A. Acute EGCG supplementation reverses endothelial dysfunction in patients with coronary artery disease. J. Am. Coll. Nutr. 2007, 26, 95-102. [CrossRef]

66. Ponzo, V.; Goitre, I.; Fadda, M.; Gambino, R.; De Francesco, A.; Soldati, L.; Gentile, L.; Magistroni, P.; Cassader, M.; Bo, S. Dietary flavonoid intake and cardiovascular risk: A population-based cohort study. J. Transl. Med. 2015, 13, 218. [CrossRef] [PubMed]

67. Serafini, M.; Del Rio, D.; Yao, D.N.; Bettuzzi, S.; Peluso, I. Chapter 12: Health benefits of tea. In Herbal Medicine: Biomolecular, and Clinical Aspects, 2nd ed.; Benzie, I.F.F., Wachtel-Galor, S., Eds.; CRC Press: Boca Raton, FL, USA, 2011; pp. 239-262.

68. Ahmed, S.; Marotte, H.; Kwan, K.; Ruth, J.H.; Campbell, P.L.; Rabquer, B.J.; Pakozdi, A.; Koch, A.E. Epigallocaetchin-3-gallate inhibits IL-6 synthesis and suppresses transsignaling by enhancing soluble gp130 production. Proc. Natl. Acad. Sci. USA 2008, 105, 14692-14697. [CrossRef] [PubMed]

69. Yun, H.J.; Yoo, W.H.; Han, M.K.; Lee, Y.R.; Kim, J.S.; Lee, S.I. Epigallocatechin-3-gallate suppresses TNF- $\alpha$-induced production of MMP-1 and -3 in rheumatoid arthritis synovial fibroblasts. Rheumatol. Int. 2008, 29, 23-29. [CrossRef] [PubMed]

70. Leong, D.J.; Choudhury, M.; Hanstein, R.; Hirsh, D.M.; Kim, S.J.; Majeska, R.J.; Schaffler, M.B.; Hardin, J.A.; Spray, D.C.; Goldring, M.B.; et al. Green tea polyphenol treatment is chondroprotective, anti-inflammatory and palliative in a mouse posttraumatic osteoarthritis model. Arthritis Res. Ther. 2014, 16, 508. [CrossRef] [PubMed]

71. Naito, Y.; Yoshikawa, T. Green tea and heart health. J. Cardiovasc. Pharmacol. 2009, 54, 385-390. [CrossRef] [PubMed] 
72. Liu, D.; Perkins, J.T.; Hennig, B. EGCG prevents PCB-126-induced endothelial cell inflammation via epigenetic modifications of NF- $\mathrm{kB}$ target genes in human endothelial cells. J. Nutr. Biochem. 2016, 28, 164-170. [CrossRef] [PubMed]

73. Donà, M.; Dell'Aica, I.; Calabrese, F.; Benelli, R.; Morini, M.; Albini, A.; Garbisa, S. Neutrophil restraint by green tea: Inhibition of inflammation, associated angiogenesis, and pulmonary fibrosis. J. Immunol. 2003, 170, 4335-4341. [CrossRef] [PubMed]

74. Akhtar, N.; Haqqi, T.M. Epigallocatechin-3-gallate suppresses the global interleukin-1beta-induced inflammatory response in human chondrocytes. Arthritis Res. Ther. 2011, 13, r93. [CrossRef] [PubMed]

75. Behfarnia, P.; Aslani, A.; Jamshidian, F.; Noohi, S. The efficacy of green tea chewing gum on gingival inflammation. J. Dent. Shiraz Univ. Med. Sci. 2016, 17, 149-154.

76. Kim, I.B.; Kim, D.Y.; Lee, S.J.; Sun, M.J.; Lee, M.S.; Li, H.; Cho, J.J.; Park, C.S. Inhibition of IL-8 production by green tea polyphenols in human nasal fibroblasts and A549 epithelial cells. Biol. Pharm Bull. 2006, 29, 1120-1125. [CrossRef] [PubMed]

77. Tang, Y.; Matsuoka, I.; Ono, T.; Inoue, K.; Kimura, J. Selective up-regulation of $\mathrm{P}_{2} \mathrm{X}_{4}$-receptor gene expression by interferon- $\gamma$ in vascular endothelial cells. J. Pharmacol. Sci. 2008, 107, 419-427. [CrossRef] [PubMed]

78. Liu, X.; Zhang, D.Y.; Zhang, W.; Zhao, X.; Yuan, C.; Ye, F. The effect of green tea extract and EGCG on the signaling network in squamous cell carcinoma. Nutr. Cancer 2011, 63, 466-475. [CrossRef] [PubMed]

79. Baba, Y.; Sonoda, J.I.; Hayashi, S.; Tosuji, N.; Sonoda, S.; Makisumi, K.; Nakajo, M. Reduction of oxidative stress in liver cancer patients by oral green tea polyphenol tablets during hepatic arterial infusion chemotherapy. Exp. Ther. Med. 2012, 4, 452-458. [CrossRef] [PubMed]

80. Tao, L.; Forester, S.C.; Lambert, J.D. The role of the mitochondrial oxidative stress in the cytotoxic effects of the green tea catechin, (-)-epigallocatechin-3-gallate, in oral cells. Mol. Nutr. Food Res. 2014, 58, 665-676. [CrossRef] [PubMed]

81. Calo, L.A.; Vertolli, U.; Davis, P.A.; Dal Maso, L.; Pagnin, E.; Ravarotto, V.; Maiolino, G.; Lupia, M.; Seccia, T.M.; Rossi, G.P. Molecular biology based assessment of green tea effects on oxidative stress and cardiac remodeling in dialysis patients. Clin. Nutr. 2014, 33, 437-442. [CrossRef] [PubMed]

82. Vester, H.; Holzer, N.; Neumaier, M.; Lilianna, S.; Nüssler, A.K.; Seeliger, C. Green tea extract (GTE) improves differentiation in human osteoblasts during oxidative stress. J. Inflamm. (Lond.) 2014, 11, 15. [CrossRef] [PubMed]

83. Sugita, M.; Kapoor, M.P.; Nishimura, A.; Okubo, T. Influence of green tea catechins on oxidative stress metabolites at rest and during exercise in healthy humans. Nutrition 2016, 32, 321-331. [CrossRef] [PubMed]

84. Jówko, E.; Sacharuk, J.; Balasinska, B.; Wilczak, J.; Charmas, M.; Ostraszewski, P.; Charmas, R. Effect of a single dose of green tea polyphenols on the blood markers of exercise-induced oxidative stress in soccer players. Int. J. Sport Nutr. Exerc. Metab. 2012, 22, 486-496. [CrossRef] [PubMed]

85. Zhao, J.; Fang, S.; Yuan, Y.; Guo, Z.; Zeng, J.; Guo, Y.; Tang, P.; Mei, X. Green tea polyphenols protect spinal cord neurons against hydrogen peroxide-induced oxidative stress. Neural Regen. Res. 2014, 9, 1379-1385. [PubMed]

86. Jówko, E.; Długołęcka, B.; Makaruk, B.; Cieśliński, I. The effect of green tea extract supplements on exercise-induced oxidative stress parameters in male sprinters. Eur. J. Nutr. 2015, 54, 783-791. [CrossRef] [PubMed]

87. Bogdanski, P.; Suliburska, J.; Szulinska, M.; Stepien, M.; Pupek-Musialik, D.; Jablecka, A. Green tea extract reduces blood pressure, inflammatory biomarkers, and oxidative stress and improves parameters associated with insulin resistance in obese, hypertensive patients. Nutr. Res. 2012, 32, 421-427. [CrossRef] [PubMed]

88. Li, M.; Liu, J.T.; Pang, X.M.; Han, C.J.; Mao, J.J. Epigallocatechin-3-gallate inhibits angiotensin II and interleukin-6-induced C-reactive protein production in macrophages. Pharmacol. Rep. 2012, 64, 912-918. [CrossRef]

89. Bhardwaj, P.; Khanna, D. Green tea catechins: Defensive role in cardiovascular disorders. Chin. J. Nat. Med. 2013, 11, 345-353. [CrossRef]

90. Son, D.J.; Cho, M.R.; Jin, Y.R.; Kim, S.Y.; Park, Y.H.; Lee, S.H.; Akiba, S.; Sato, T.; Yun, Y.P. Antiplatelet effect of green tea catechins: A possible mechanism through arachidonic acid pathway. Prostaglandins Leukot. Essent. Fatty Acids 2004, 71, 25-31. [CrossRef] [PubMed] 
91. Jin, Y.R.; Im, J.H.; Park, E.S.; Cho, M.R.; Han, X.H.; Lee, J.J.; Lim, Y.; Kim, T.J.; Yun, Y.P. Antiplatelet activity of epigallocatechin gallate is mediated by the inhibition of PLC $\gamma 2$ phosphorylation, elevation of PGD2 production, and maintaining calcium-ATPase activity. J. Cardiovasc. Pharmacol. 2008, 51, 45-54. [CrossRef] [PubMed]

92. Ok, W.J.; Cho, H.J.; Kim, H.H.; Lee, D.H.; Kang, H.Y.; Kwon, H.W.; Rhee, M.H.; Kim, M.; Park, H.J. Epigallocatechin-3-gallate has an anti-platelet effect in a cyclic AMP-dependent manner. J. Atheroscler. Thromb. 2012, 19, 337-348. [CrossRef] [PubMed]

93. Lee, D.H.; Kim, Y.J.; Kim, H.H.; Cho, H.J.; Ryu, J.H.; Rhee, M.H.; Park, H.J. Inhibitory effects of epigallocatechin-3-gallate on microsomal cyclooxygenase-1 activity in platelets. Biomol. Ther. 2013, 21, 54-59. [CrossRef] [PubMed]

94. Iida, Y.; Doi, T.; Matsushima-Nishiwaki, R.; Tokuda, H.; Ogura, S.; Kozawa, O.; Iida, H. (-)-Epigallocatechin gallate selectively inhibits adenosine diphosphate-stimulated human platelet activation: Suppression of heat shock protein 27 phosphorylation via p38 mitogen-activated protein kinase. Mol. Med. Rep. 2014, 10, 1383-1388. [CrossRef] [PubMed]

95. Jain, K.S.; Kathiravan, M.K.; Somani, R.S.; Shisloo, C.J. The biology and chemistry of hyperlipidemia. Bioorg. Med. Chem. 2007, 15, 4674-4699. [CrossRef] [PubMed]

96. Parthasarathy, S.; Raghavamenon, A.; Gareinabi, M.O.; Santanam, N. Oxidized low-density lipoprotein. Methods Mol. Biol. 2010, 610, 403-417. [PubMed]

97. Kim, A.; Chiu, A.; Barone, M.K.; Avino, D.; Wang, F.; Coleman, C.I.; Phung, O.J. Green tea catechins decrease total and low-density lipoprotein cholesterol: A systematic review and meta-analysis. J. Am. Diet. Assoc. 2011, 111, 1720-1729. [CrossRef] [PubMed]

98. Zheng, X.X.; Xu, Y.L.; Li, S.H.; Liu, X.X.; Hui, R.; Huang, X.H. green tea intake lowers fasting serum total and LDL cholesterol in adults: A meta-analysis of 14 randomized controlled trials. Am. J. Clin. Nutr. 2011, 94, 601-610. [CrossRef] [PubMed]

99. Wu, A.H.; Spicer, D.; Stanczyk, F.Z.; Tseng, C.C.; Yang, C.S.; Pike, M.C. Effect of 2 month controlled green tea intervention on lipoprotein cholesterol, glucose, and hormone levels in healthy postmenopausal women. Cancer Prev. Res. (Phila.) 2012, 5, 393-402. [CrossRef] [PubMed]

100. Khalesi, S.; Sun, J.; Buys, N.; Jamashidi, A.; Nikbakht-Nasrabadi, E.; Khosravi-Boroujeni, H. Green tea catechins and blood pressure: A systematic review and meta-analysis of randomized controlled trials. Eur. J. Nutr. 2014, 53, 1299-1311. [CrossRef] [PubMed]

101. Ohmori, R.; Kondo, K.; Momiyama, Y. Antioxidant beverages: Green tea intake and coronary artery disease. Clin. Med. Insights Cardiol. 2014, 8 (Suppl. 3), 7-11. [CrossRef] [PubMed]

102. Onakpoya, I.; Spencer, E.; Heneghan, C.; Thompson, M. The effect of green tea on blood pressure and lipid profile: A systematic review and meta-analysis of randomized clinical trials. Nutr. Met. Cardiovasc. Dis. 2014, 24, 823-836. [CrossRef] [PubMed]

103. Takechi, R.; Alfonso, H.; Hiramatsu, N.; Ishisaka, A.; Tanaka, A.; Tan, L.B.; Lee, A.H. Elevated plasma and urinary concentrations of green tea catechins associated with improved plasma lipid profile in healthy Japanese women. Nutr. Res. 2016, 36, 220-226. [CrossRef] [PubMed]

104. Tian, C.; Huang, Q.; Yang, L.; Légaré, S.; Angileri, F.; Yang, H. Green tea consumption is associated with reduced incident CHD and improved CHD-related biomarkers in the Dongfeng-Tongji cohort. Sci. Rep. 2016, 6, 24353. [CrossRef] [PubMed]

105. Suzuki-Sugihara, N.; Kishimoto, Y.; Saita, E.; Taguchi, C.; Kobayashi, M.; Ichitani, M.; Ukawa, Y.; Sagesaka, Y.M.; Suzuki, E.; Kondo, K. Green tea catechins prevent low-density lipoprotein oxidation via their accumulation in low-density lipoprotein particles in humans. Nutr. Res. 2016, 36, 16-23. [CrossRef] [PubMed]

106. Reygaert, W.C. Potential for Prevention of Infection by Green Tea. In Green Tea and Health: Antioxidant Properties, Consumption and Role in Disease Prevention; Powell, N., Ed.; Nova Science Pub Inc.: Hauppauge, NY, USA, 2015.

107. Gaur, S.; Agnihotri, R. Green tea: A novel functional food for the oral health of older adults. Geriatr. Gerontol. Int. 2014, 14, 238-250. [CrossRef] [PubMed]

108. Awadalla, H.I.; Ragab, M.H.; Bassuoni, M.W.; Fayed, M.T.; Abbas, M.O. A pilot study of the role of green tea use on oral health. Int. J. Dent. Hyg. 2011, 9, 110-116. [CrossRef] [PubMed] 
109. Rassameemasmaung, S.; Phusudsawang, P.; Sangalungkarn, V. Effect of green tea mouthwash on oral malodor. ISRN Prev. Med. 2012, 2013, 975148. [CrossRef] [PubMed]

110. Kushiyama, M.; Shimazaki, Y.; Murakami, M.; Yamashita, Y. Relationship between intake of green tea and periodontal disease. J. Periodontol. 2009, 80, 372-377. [CrossRef] [PubMed]

111. Kato, M.T.; Magalháes, A.C.; Rios, D.; Hannas, A.R.; Attin, T.; Buzalaf, M.A. Protective effect of green tea on dentin erosion and abrasion. J. Appl. Oral Sci. 2009, 17, 560-564. [CrossRef] [PubMed]

112. Hara, K.; Ohara, M.; Hayashi, I.; Hino, T.; Nishimura, R.; Iwasaki, Y.; Ogawa, T.; Ohyama, Y.; Sugiyama, M.; Amano, H. The green tea polyphenol (-)-epigallocatechin gallate precipitates salivary proteins including alpha-amylase: Biochemical implications for oral health. Eur. J. Oral Sci. 2012, 120, 132-139. [CrossRef] [PubMed]

113. Narotzki, B.; Levy, Y.; Aizenbud, D.; Reznick, A.Z. Green tea and its major polyphenol EGCG increase the activity of oral peroxidases. Adv. Exp. Med. Biol. 2013, 756, 99-104. [PubMed]

(C) 2017 by the author; licensee MDPI, Basel, Switzerland. This article is an open access article distributed under the terms and conditions of the Creative Commons Attribution (CC-BY) license (http://creativecommons.org/licenses/by/4.0/). 